\title{
IDENTIFICATION OF A THROMBOPLASTIN INHIBITOR IN SERUM AND IN PLASMA ${ }^{1}$
}

\author{
BY GERARD F. LANCHANTIN AND ARNOLD G. WARE \\ (From the Department of Biochemistry and Nutrition, University of Southern California, \\ School of Medicine, and the Laboratory Division of the Los Angeles County \\ Hospital, Los Angeles, California)
}

(Submitted for publication October 20, 1952; accepted January 7, 1953)

Thromboplastin inhibitors in the blood have received little attention until recently. Tocantins has presented evidence during the past decade which supports the view that a thromboplastin inhibitor exists in normal plasma $(1,2)$. His work has culminated in the isolation of a lipid inhibitor from normal human plasma which he named "anticephalin" (3). This factor is a strong inhibitor of clotting apparently acting as a thromboplastin antagonist. It is isolated as the methyl alcoholsoluble, ether-soluble fraction of plasma and is obtained from the hemophiliac in a form several times more active than normal. This fundamental information is made even more interesting by Tocantins' recent observations that hemophilic plasma euglobulins, after proper dilution, can promote clotting in whole hemophilic plasma (4).

Overman and Wright described an inositol phosphatide which was separated from plasma as well as from tissues and from soy beans $(5,6)$. This lipid is an inhibitor of clotting which was thought to act in a complex manner involving thromboplastin. A method of preparation of the inhibitor was not published but it is assumed that the procedure was similar to that described by Tocantins (3). Fiala has described a protein inhibitor of clotting which is adsorbed from oxalated plasma by barium carbonate, barium sulfate and celite ( 7 , 8). The manner of action of this inhibitor was not described.

Much more impressive as an indication of a thromboplastin inhibitor in serum is the work of Schneider (9) and of Thomas (10). These investigators demonstrated independently that human serum can effectively inactivate tissue thromboplastin. Both used an in vivo assay technic for

1This investigation was supported by the United States Public Health Service (RG 2684) and by the Medical Research and Development Board, Office of the Surgeon General, Department of the Army, under Contract No. DA-49-007-MD-193. thromboplastin which was based on the ability of this substance to kill mice when injected intravenously. The rapid death which resulted from injection of toxic doses could be prevented by preliminary incubation of the thromboplastin with serum. The inhibitor in serum was found to be heat labile. Thomas was able to show that serum had no effect on thromboplastin when calcium was removed by dialysis or by addition of oxalate. $\mathrm{He}$ isolated thromboplastin by high speed centrifugation after it had been incubated with serum in the presence of calcium. The sedimented material had no effect when injected into mice but its clotting activity was completely restored by addition of oxalate. The inhibitor was separated from serum with ammonium sulfate between the levels of 25 and 50 per cent saturation and was not dialyzable through cellophane membranes.

Thomas' experiments provided proof that thromboplastin is inactivated by incubation with serum in the presence of calcium (10). Peculiarly enough, however, neither Schneider nor Thomas was able to demonstrate this effect successfully when in vitro thromboplastin assay systems were used. The incubation of thromboplastin with serum and calcium appeared to result in acceleration of clotting.

Making use of Thomas' observations, McClaughry succeeded in identifying a thromboplastin inhibitor from bovine lung extract (11). The thromboplastin in this preparation, which contained large amounts of blood, was first sedimented by high speed centrifugation in the presence of calcium ions. The inhibitor was then dissociated from the sediment by addition of oxalate followed by subsequent separation from the thromboplastin. It was then shown to have the property of inactivating thromboplastin in the presence of calcium ions and it had no demonstrable effect on other purified clotting components. The inhibitor was non-dialyzable, and gave positive tests for protein. 
In the work to be presented, an in vitro technic is described for identification of a thromboplastin inhibitor in human serum and in treated human plasma. The factor is heat labile, non-dialyzable and can be separated from human serum by ammonium sulfate fractionation. It was found to be quite stable in serum at room temperature. It requires calcium ions in order to inactivate thromboplastin and its effect is rapidly reversed by removal of the calcium.

\section{EXPERIMENTAL}

\section{A. Materials and Methods}

1. Saline-imidazole buffer. Buffer of $\mathrm{pH} 7.4$ was prepared by dissolving 3 grams of imidazole, C.P. (Edcan Laboratories) in $975 \mathrm{ml}$. of 0.7 per cent sodium chloride solution and $25 \mathrm{ml}$. of $0.5 \mathrm{~N}$ hydrochloric acid.

2. Thromboplastin. Most of the work to be described has been done with thromboplastin of human origin, although rabbit brain thromboplastin has been demonstrated to behave similarly. Human brains, removed from cadavers not more than 24 hours post mortem, were used as a source of thromboplastin. The brains were freed of blood vessels, minced in a Waring Blendor and dried with acetone by standard technics. Five grams of dried brain were extracted with $100 \mathrm{ml}$. of 0.9 per cent sodium chloride containing $0.002 \mathrm{M}$ potassium oxalate. ${ }^{2}$ The extraction was carried out at $45^{\circ}$ to $50^{\circ} \mathrm{C}$. for approximately 30 minutes with occasional stirring. The suspension of brain was then freed of gross particles by light centrifugation.

The work to be described demanded a semi-purified thromboplastin preparation which could be sedimented by high speed centrifugation and recovered in high yields. This was accomplished by centrifuging the crude product described above for two hours at 28,000 G. in an angle head. The white pellet of thromboplastin was then resuspended in its original volume of oxalated saline with the aid of a Potter-Elvehjem glass homogenizer. This process was then repeated two more times. After the last centrifugation, the sediment was taken up in salineimidazole buffer to 10 times its original volume. This preparation was almost water clear and was found to retain its activity when stored for several months at $-20^{\circ} \mathrm{C}$.

3. Prothrombin-free beef plasma. This reagent was used in our clotting system to provide a stable source of fibrinogen and accelerator globulin. It has been used quite successfully for a number of years in a modified onestage prothrombin test (13). Freshly collected beef blood was added to a solution of $0.1 \mathrm{M}$ potassium oxalate (proportion of 9 to 1). The plasma was removed after centrifugation and mixed with freshly precipitated barium sulfate. Equimolar solutions of barium chloride and sodium sulfate were mixed and the precipitate was washed

${ }^{2}$ The inclusion of a small amount of oxalate in the saline solution results in a more active product $(12,13)$. twice with distilled water. Two grams of centrifuged packed barium sulfate (dry weight) were added to each $100 \mathrm{ml}$. of plasma, thoroughly dispersed and allowed to stand at room temperature for about 30 minutes. The barium sulfate was then removed by centrifugation and each $100 \mathrm{ml}$. of plasma was run through a Seitz filter of 40 to 50 per cent asbestos content. The plasma was then dialyzed against saline until free of oxalate and diluted with an equal volume of 0.9 per cent sodium chloride containing 0.6 per cent imidazole. The resultant solution was then adjusted to $\mathrm{pH} 7.4$ with $0.5 \mathrm{~N}$ hydrochloric acid and frozen at $-20^{\circ} \mathrm{C}$.

4. Clotting system for demonstrating thromboplastic activity. Prothrombin-free beef plasma was used as a stable source of fibrinogen and accelerator globulin. As a source of prothrombin, freshly-reconstituted dried human plasma was employed. The plasma had been dried originally in 1945 and was found to contain a normal amount of prothrombin which remained stable for many hours after reconstitution (13). For the purpose of this test it was diluted with distilled water to 10 times the volume of the original plasma. Thromboplastin and an optimal amount of calcium were also added to provide a clotting system which was quite sensitive to changes in thromboplastic activity. The entire system was easily reproduced on successive working days and gave remarkably constant clotting times with thromboplastin of known activity.

All tests were carried out at $37^{\circ} \mathrm{C}$. The reagents were preheated to $37^{\circ} \mathrm{C}$. and then added to $75 \times 10 \mathrm{~mm}$. test tubes in the following amounts and order:
$0.1 \mathrm{ml}$. of prothrombin-free beef plasma
$0.1 \mathrm{ml}$. of reconstituted dried human plasma ( 1 to 10 )
$0.1 \mathrm{ml}$. of buffer
$0.1 \mathrm{ml}$. of thromboplastin
$0.1 \mathrm{ml}$. $0.015 \mathrm{M}$ calcium chloride (optimum 0.01 to $0.02 \mathrm{M}$ )

In the absence of thromboplastin, this system clotted in approximately 480 seconds. With a thromboplastin which gives 12 to 13 seconds with normal plasma in the one-stage prothrombin time, this system will clot in approximately 33 seconds. Using the purified thromboplastin described above, clotting times of about 40 seconds are obtained. Dilutions of this thromboplastin result in progressively longer clotting times which are indicated in Figure 1. The logarithm of the thromboplastin concentration in this system was found to be a straight line function of the negative logarithm of the clotting time over a wide range.

\section{B. Results}

\section{Demonstration of thromboplastin inhibitors} in serum. When normal human serum was substituted in the clotting system above in place of the buffer, a small amount of acceleration of clotting was usually noted. When the thromboplastin, 


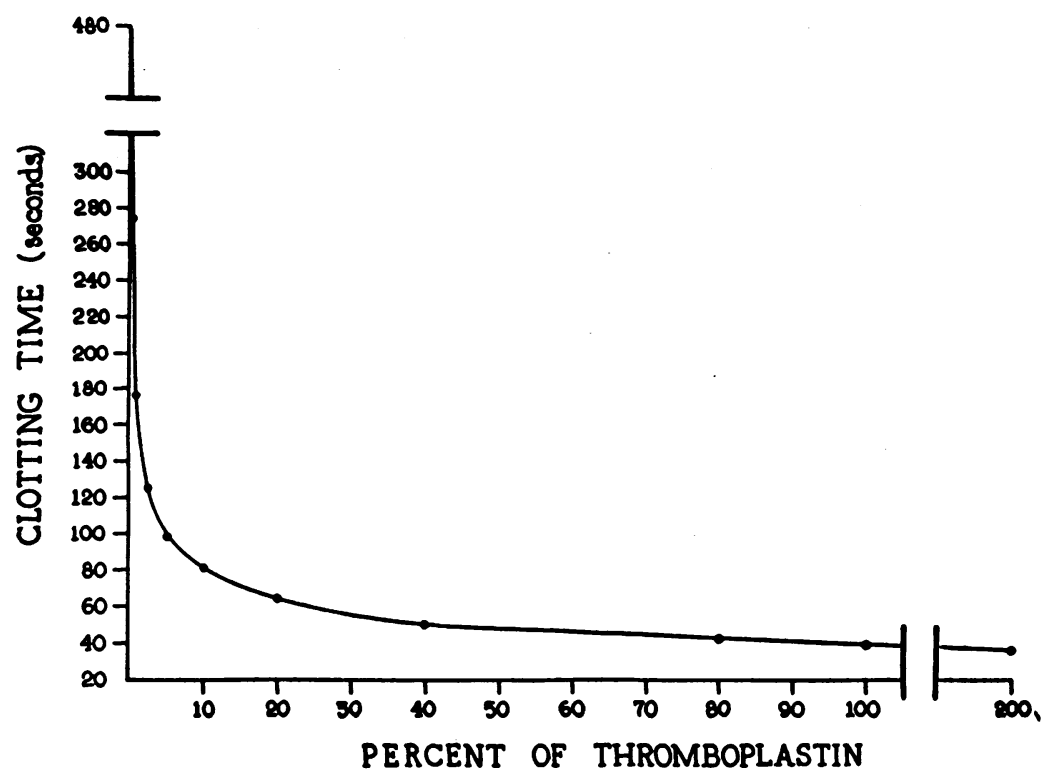

Fig. 1. Clotting Times Produced by Thromboplastin of Various CONCENTRATIONS

Clotting system described in text.

calcium chloride and serum were allowed to incubate at $37^{\circ} \mathrm{C}$. before being added to the other two components of the clotting system, variable responses were obtained with different sera. As a general rule, an acceleration phase developed during the first few minutes which was then followed by inhibition. Fresh serum usually exhibited more acceleration than aged serum. A typical experiment with aged serum is presented in Figure 2.

It was suspected that the acceleration phase was dependent upon the amount of prothrombin remaining in the serum as well as upon the evolu-

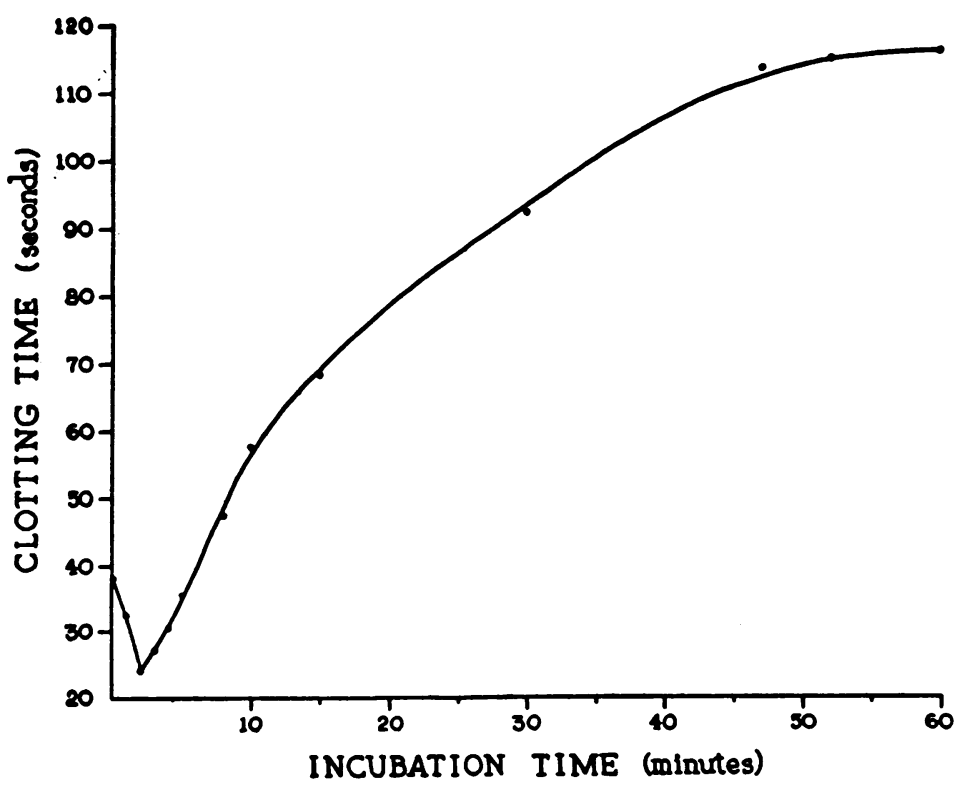

Fig. 2. The Clotting Times Produced by Untreated Aged Seruy, Thromboplastin and Calcium Chloride Incubated together at $37^{\circ} \mathrm{C}$. and Added to a Clotting System at Intervals 
tion of an accelerator which was not present in our test system. Such a factor has been described recently in the literature (14-17). Since this factor, as well as prothrombin, is known to be adsorbed on barium sulfate it was of interest to test the inhibition with serum which had been adsorbed with barium sulfate. Previous experience had shown that the accelerator factors can be removed more efficiently with barium sulfate when oxalate is present. Therefore, oxalate was added to the serum to a strength of $0.02 \mathrm{M}$ and freshly precipitated barium sulfate was added at a concentration of 2 grams (dry weight) per $100 \mathrm{ml}$. of oxalated serum. The suspension was dispersed thoroughly, allowed to stand at $37^{\circ} \mathrm{C}$. for $45 \mathrm{~min}$ utes and the barium sulfate was removed by centrifugation. The serum was then dialyzed against saline until free of oxalate and adjusted to $\mathrm{pH} 7.4$ with 0.5 per cent acetic acid.

When the barium sulfate-adsorbed serum was incubated with thromboplastin and calcium chloride, a marked inhibition of thromboplastin activity was apparent almost immediately. When calcium was eliminated during the incubation period, the inhibition of thromboplastin was much less. The results of a typical experiment are presented in Figure 3. When expressed in terms of thromboplastin activity (ordinates to the right of Figure 3). it is apparent that the serum was capable of inactivating more than 95 per cent of the thromboplastin.

When a smaller amount of thromboplastin was incubated with adsorbed serum in the presence of calcium, the inhibition took place in a similar manner (Figure 4). The thromboplastin used for this experiment (Figure 4) was one-tenth the concentration employed previously. The clotting activity was reduced to a level of 213 seconds after a 100 minute incubation period with serum. When the more concentrated thromboplastin was used (Figure 3 ), the inhibition reached a maximum at a clotting activity of 107 seconds. The difference in actual thromboplastin concentration between 107 and 213 seconds is approximately five-fold (see Figure 1). Thus, the activity of the thromboplastin remaining after incubation appears to be

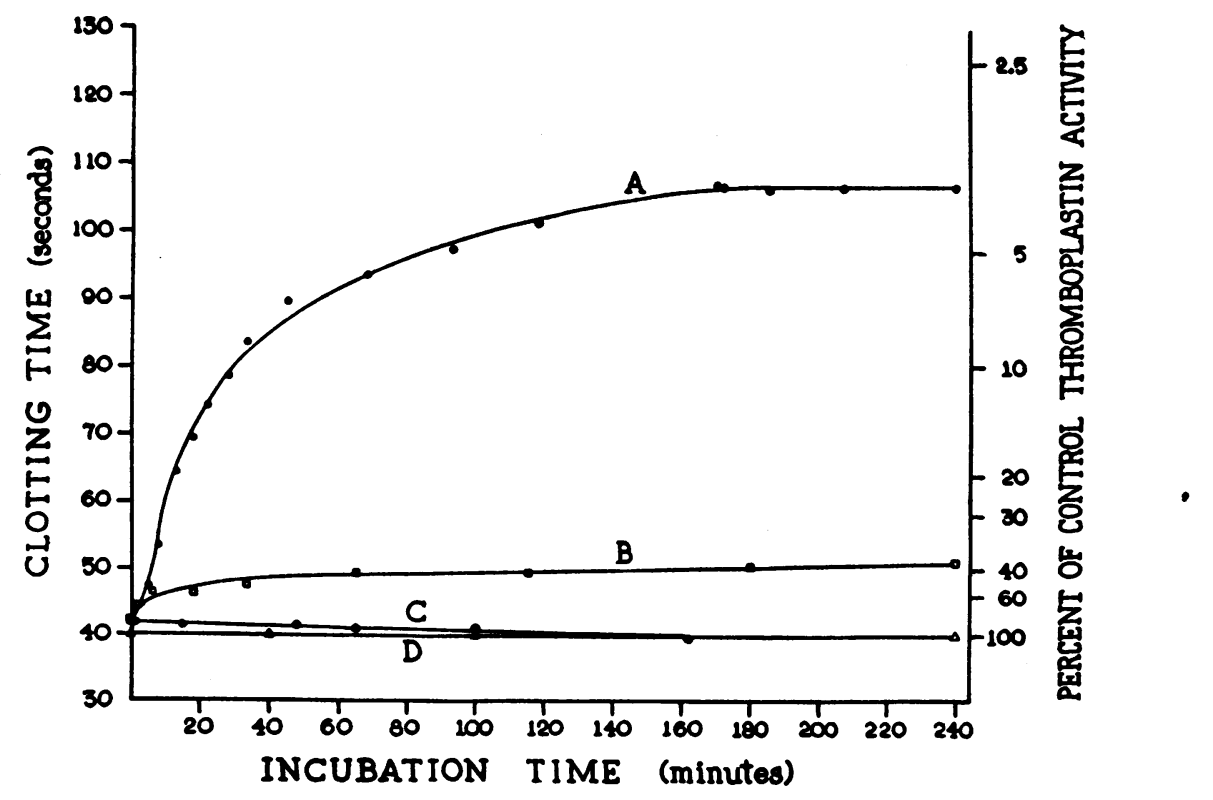

Fig. 3. The Clotming Trmes Produced by Bartuy Sulfate-Adsorard Smeuy AND Thromboplastin INCUBATEd together at $37^{\circ}$ C. WITH aNd without CalctuM and Adied to a Clotting System at Intervals

\section{Reagents incubated}

A. Adsorbed serum, thromboplastin and calcium

B. Adsorbed serum and thromboplastin

C. Adsorbed serum and calcium

D. Thromboplastin, calcium and buffer 


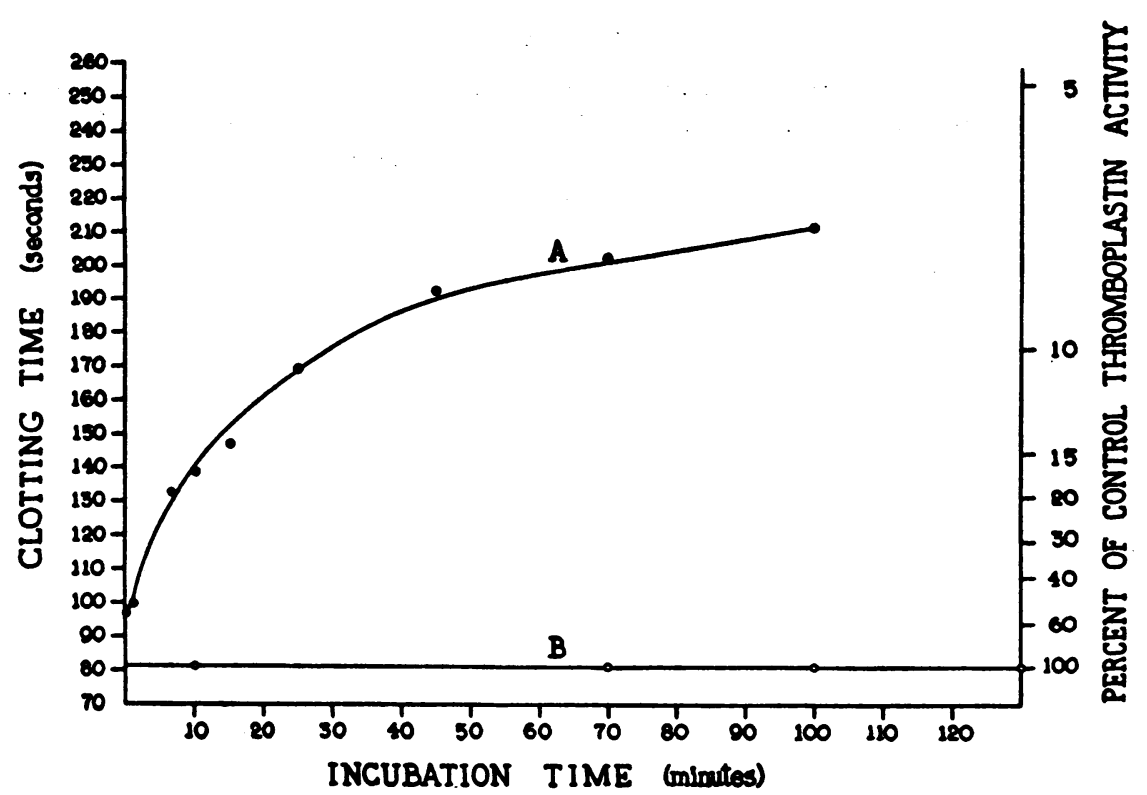

Fig. 4. The Clotting Times Produced by Barium Sulfate-Adsorbed Serum, Dinuted Thromboplastin and Calcium Chloride Incubated together at $37^{\circ} \mathrm{C}$. and Added to a Clotring System at Intervals

\section{Reagents incubated}

A. Adsorbed serum, diluted thromboplastin and calcium

B. Diluted thromboplastin, calcium and buffer

proportional to the quantity of thromboplastin used.

2. Sedimentation of inhibited thromboplastin and subsequent reactivation by removal of calcium. To demonstrate that the phenomenon illustrated in Figures 3 and 4 is actual inhibition of thromboplastin, the following experiments were performed. One volume of barium sulfate-adsorbed serum was incubated with 1 volume of thromboplastin and 1 volume of $0.015 \cdot \mathrm{M}$ calcium chloride for a period of two hours at $37^{\circ} \mathrm{C}$. The thromboplastin was then sedimented at $28,000 \mathrm{G}$. for two hours at $0^{\circ}$ C. At the end of this period the supernatant was carefully removed by decantation and the thromboplastin was resuspended in 3 volumes of buffer containing $0.005 \mathrm{M}$ calcium chloride. The suspension was dispersed with the aid of a glass homogenizer before its clotting activity was tested. A duplicate experiment was performed in which the thromboplastin was treated in exactly the same manner except that it was resuspended and homogenized in buffer alone, the calcium chloride being added immediately before testing its clotting ability. Two controls were also run; one in which thromboplastin was incubated with calcium and buffer and the other in which thromboplastin was incubated with serum and buffer. Both were then sedimented, resuspended and homogenized in buffer containing $0.005 \mathrm{M}$ calcium chloride.

The clotting times of the four thromboplastins described above were then determined as before by adding $0.3 \mathrm{ml}$. of each resuspended homogenized sediment to $0.2 \mathrm{ml}$. of an equal mixture of prothrombin-free beef plasma and reconstituted human plasma. The clotting times are indicated in Table I along with the apparent amount of thromboplastin activity interpolated from Figure 1. Except in experiment 2 of Table I, the results are the average of two experiments.

It is apparent from the first experiment in Table I that serum actually inhibits thromboplastin in the presence of calcium. Only 5 per cent of the activity remained whereas, in experiment 3 , thromboplastin not incubated with serum was demonstrated to be completely recoverable. It is of interest that there was no apparent difference in the quantity of the thromboplastin sediments in experiments 1 and 3 . This indicates that the inhibitor does not change appreciably the physical properties of the thromboplastin. The action 
TABLE I

Clotting properties of thromboplastin after incubation with adsorbed, dialyzed serum in the presence and absence of calcium; the thromboplastin was sedimented after incubation and then reconstituted in buffer or in buffer containing calcium

\begin{tabular}{|c|c|c|c|c|}
\hline Exp. No. & $\begin{array}{l}\text { MIXTURE } \\
\text { INCUBATED } \\
\text { FOr } 2 \text { HOUR } \\
\text { AT } 370 \text { C. } \\
\end{array}$ & $\begin{array}{l}\text { THROMBOPLASTIN } \\
\text { SEDIMENTED ANA } \\
\text { RECONSTI TUTED IN }\end{array}$ & $\begin{array}{l}\text { CLOTTING } \\
\text { TIME in } \\
\text { SECONDS }\end{array}$ & $\begin{array}{l}\text { PER CENT } \\
\text { THROMEOPLASTIN } \\
\text { ACTIVITY } \\
\text { RECOVERED } \\
\end{array}$ \\
\hline I & $\begin{array}{l}\text { Serun } \\
\text { Calciyn } \\
\text { TPLN. }\end{array}$ & $\begin{array}{l}0.005 \text { M } \\
\text { Calciun }\end{array}$ & 108 & 6 \\
\hline 2 & $\begin{array}{l}\text { Sorun } \\
\text { Calcium } \\
\text { TPLN. }\end{array}$ & Buffer & 42 & 86 \\
\hline 3 & $\begin{array}{l}\text { Buffer } \\
\text { Calcium } \\
\text { TPLN. }\end{array}$ & $\begin{array}{l}0.005 \\
\text { Calciun in } \\
\text { Buffer }\end{array}$ & 40 & 100 \\
\hline 4 & $\begin{array}{l}\text { Sorun } \\
\text { Buffer } \\
\text { TPux. }\end{array}$ & $\begin{array}{l}\text { 0.005in } \\
\text { Calcium in } \\
\text { Buffer }\end{array}$ & 40 & 100 \\
\hline 5 & \multicolumn{2}{|c|}{$\begin{array}{l}\text { Supernatant from Exp.' } \\
\text { which contained } 0.00 \delta^{\prime} M \\
\text { Calcium and buffer. }\end{array}$} & 465 & Less than I \\
\hline
\end{tabular}

of the inhibitor was completely prevented by eliminating calcium during the incubation period (experiment 4) and the thromboplastin was actually recovered in 100 per cent yield. Experiment 2 provides confirmation of Thomas' observations that the effect of the inhibitor can be reversed by removal of calcium (10). In this experiment, the serum and thromboplastin were incubated in the presence of calcium but the thromboplastin sediment was resuspended in a calcium-free medium. This resulted in the regeneration of most of the thromboplastic activity.

The supernatant serum from experiment 1 was examined for clotting properties after the thromboplastin had been sedimented. The clotting time of 465 seconds was almost the same as the clotting time of the system without serum or thromboplastin (480 seconds). This indicates that very little active thromboplastin remained in the supernatant and also eliminates the possibility of the production of an inhibitor when thromboplastin, serum and calcium were incubated together.

3. Effect of oxalate upon the demonstration of thromboplastin inhibitor in serum. An assay system was originally used which contained oxalate in the prothrombin-free beef plasma. This was compensated for by adding enough calcium chloride in the final step to react with the oxalate and to provide an optimal amount to achieve the short- est clotting time. It is of interest that this system did not demonstrate as much inhibition of thromboplastin as the oxalate-free system described earlier. This was interpreted to mean that the oxalate caused partial reversal of the inhibition during the short period when the thromboplastin and the prothrombin-free beef plasma were in contact before clotting took place.

In order to demonstrate the effect of oxalate, prothrombin-free beef plasma was prepared containing two different concentrations of potassium oxalate, $0.015 \mathrm{M}$ and $0.03 \mathrm{M}$. The clotting system was examined using untreated thromboplastin to find the optimum level of calcium chloride. This was found to be $0.025 \mathrm{M}$ for both oxalate concentrations and the clotting times were found to be slightly shorter when oxalate was present. The thromboplastin was incubated with equal volumes of barium sulfate-adsorbed serum and $0.025 \mathrm{M}$. calcium chloride. At intervals, aliquots were removed and tested for clotting activity as before except the oxalate containing prothrombin-free beef plasma was used. The results are indicated in Figure 5, and compared to the oxalate-free system. It is apparent that thromboplastic activity is influenced by the presence of soluble oxalates. Much better success has been achieved in demonstrating inhibition of thromboplastin when oxalate-free systems are used. 


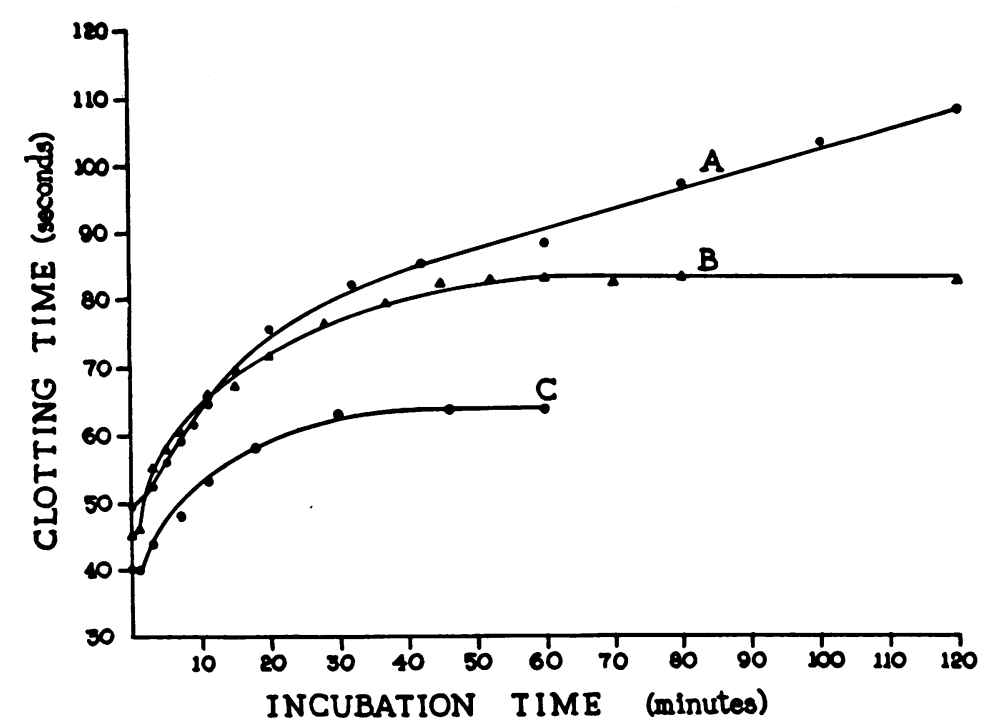

Fig. 5. The Effect of Oxalate on the Activity of Thromboplastin Incubated with Barium Sulfate-Adsorbed Serum and Calcium
A. No oxalate present
B. $0.015 \mathrm{M}$ oxalate in the prothrombin-free beef plasma
C. $0.03 \mathrm{M}$ oxalate in the prothrombin-free beef plasma
Optimum calcium was provided in each experiment.

4. Properties of the inhibitor in serum. The results reported above are reproducible with both fresh and aged human serum. The inhibitor appears to be stable when frozen at $-20^{\circ} \mathrm{C}$. No inhibitor activity can be detected in serum heated to $56^{\circ} \mathrm{C}$. for 30 minutes. It has been found that the inhibitor becomes quite unstable after the serum is dialyzed and frozen. It is not yet known whether this instability is the result of the removal of calcium.

The inhibitor appears to be almost entirely precipitated from adsorbed serum with ammonium sulfate between the levels of 40 and 50 per cent of saturation at $0^{\circ} \mathrm{C}$. The inhibitor isolated in this manner appears to be water soluble. It deteriorates somewhat when frozen in solution and stored at $-20^{\circ} \mathrm{C}$. but the activity is retained if it is dried immediately from the frozen state. It is not possible to reverse the action of the inhibitor with protamine sulfate. When thromboplastin is combined with adsorbed serum and calcium it is not possible to demonstrate the production of a thrombin inhibitor.

5. Inhibitor levels in plasma. When barium sulfate-adsorbed plasma was tested for thromboplastin inhibitor in the manner described above the results were similar to serum except that accelerators appeared to mask the effect somewhat.

\section{DISCUSSION}

This investigation has provided additional support for the existence of a factor in human plasma and serum which inhibits tissue thromboplastin and confirms Thomas' experiments which indicate that the inhibitor requires calcium and that removal of the calcium will reverse the reaction. Other investigators have been only partly successful in demonstrating this inhibition with in vitro assay systems. The reason for this appears to be two-fold: 1) clot accelerators which are produced by incubation of thromboplastin with serum and calcium have masked part of the inhibition and 2) the inclusion of oxalate in the clotting system causes a partial reversal of the thromboplastic inhibition.

The question arises as to the nature of the inhibitory activity. The evidence available indicates that the inhibitor is bound to the active groups of the thromboplastin molecule in a manner which is easily reversed by removal of calcium ions. The work of McClaughry (11) which was cited earlier 
lends strong support to this thesis. He was able to isolate the inhibitor by adsorbing it on thromboplastin in the presence of calcium and then removing it by adding oxalate.

A comparison of the properties of this inhibitor with the lipid inhibitor of Tocantins (3) was made. The latter was more stable to heat and its inhibitory action on prothrombin conversion to thrombin was not dependent on incubation with thromboplastin. Ammonium sulfate fractions of thromboplastin inhibitor did not contain significant amounts of lipid inhibitor (18) even though the original plasma yielded amounts comparable to those reported by Tocantins. These observations indicate that the two factors are not the same.

The thromboplastin inhibitor is also different from the protein inhibitor recently described by Fiala $(7,8)$. This investigator reports that his factor is adsorbed on barium carbonate, barium sulfate, and celite. The latter, which was reported to be the most efficient adsorbing agent, has no demonstrable effect on the thromboplastin inhibitor of serum. Similarly, there is no observable change in the thromboplastin inactivating property of serum when it is adsorbed with 10 times the amount of barium sulfate recommended above.

The part played by this inhibitor in the maintenance of blood fluidity may be of importance. Tocantins has demonstrated that dilution of blood in vitro (4) or in vivo as the result of severe hemorrhage (19) will accelerate clotting. This effect may be due to dilution of a thromboplastin inhibitor. It is also possible that plasma contains a thromboplastin-inhibitor complex which liberates thromboplastin when calcium is removed. Such a mechanism could readily explain the hyper-coagulability of freshly collected oxalated or citrated plasma. Recently, Honorato has found that normal and hemophilic bloods demonstrate significantly faster clotting when the calcium concentration is decreased (20). It has also been suggested by a number of investigators that the intravenous injection of oxalate causes a coagulant effect $(21,22)$. This has been reported to take place in the normal person as well as in the hemophiliac (23-25). A study of this problem is being carried out in this laboratory with calcium-binding agents. Preliminary experiments have shown that sudden binding of a portion of the blood calcium will produce a significant coagulant effect in some hemophiliacs (18). The coagulant effect is of short duration and appears to be only a fraction of the response obtained with fresh normal blood.

\section{SUMMARY}

Evidence is provided which lends additional support for the existence of a factor in human serum and plasma which inhibits tissue thromboplastin.

The inhibitor is heat-labile $\left(56^{\circ}\right.$ C. $)$, nondialyzable and can be separated from serum by ammonium sulfate between the levels of 40 and 50 per cent saturation. It is stable in serum at room temperature. It appears to be different from the lipid inhibitors described by others.

The inhibitor appears to act on the thromboplastin only in the presence of calcium. Its effect can be reversed by removal of the calcium, thus restoring the original clotting properties of the thromboplastin.

The role of this inhibitor in the maintenance of blood fluidity may be of some importance.

\section{ACKNOWLEDGMENTS}

The authors wish to acknowledge the helpful advice and suggestions made during the course of this work by Drs. John B. Field, Robert I. McClaughry, Merle L. Lewis, and John W. Mehl. We also wish to express our appreciation to Dr. Freemont E. Davis, Miss Angelyn A. Konugres, and the staff of the Transfusion Laboratory, Los Angeles County Hospital, for their cooperation in obtaining samples of blood used in these experiments.

\section{REFERENCES}

1. Tocantins, L. M., Demonstration of antithromboplastic activity in normal and hemophilic plasmas. Am. J. Physiol., 1943, 139, 265.

2. Tocantins, L. M., Relation of contacting surface and anticephalin activity to the maintenance of the fluidity and coagulability of blood. Blood, 1946, 1, 156.

3. Tocantins, L. M., and Carroll, R. T., Separation and assay of a lipid antithromboplastin from human brain, blood, plasma and plasma fractions. Tr. of the Second Conference on Blood Clotting and Allied Problems. Josiah Macy Jr. Foundation, 1949, 11.

4. Tocantins, L. M., Carroll, R. T., and Holburn, R. H., The clot accelerating effect of dilution on blood and plasma. Relation to the mechanisms of coagulation of normal and hemophilic blood. Blood, 1951, 6, 720.

5. Overman, R. S., and Wright, I. S., A new blood clotting inhibitor. J. Biol. Chem., 1948, 174, 759. 
6. Overman, R. S., The chemical purification and mode of action of a thromboplastic inhibitor. $\mathrm{Tr}$. of the Second Conference on Blood Clotting and Allied Problems. Josiah Macy Jr. Foundation, 1949, 29.

7. Fiala, S., A thermolabile inhibitor of plasma coagulation. Nature, 1951, 167, 279.

8. Fiala, S., On the role of a protein inhibitor in the first stage of blood coagulation. Arch. Internat. de physiol., 1951, 58, 386.

9. Schneider, C. L., The active principle of placental toxin: thromboplastin; its inactivator in blood: antithromboplastin. Am. J. Physiol., 1947, 149, 123.

10. Thomas, L., Studies on the intravascular thromboplastic effect of tissue suspensions in mice. II. A factor in normal rabbit serum which inhibits the thromboplastic effect of the sedimentable tissue component. Bull. Johns Hopkins Hosp., 1947, 81, 26.

11. McClaughry, R. I., The specificity of antithromboplastic activity. J. Michigan M. Soc., 1950, 49, 685.

12. Brambel, C. E., Prothrombin clotting time determination. Mercy hospital modification of Quick's procedure. Tr. of the First Conference on Blood Clotting and Allied Problems. Josiah Macy Jr. Foundation, 1948, 173.

13. Ware, A. G., and Stragnell, R., An improved onestage prothrombin method. Am. J. Clin. Path.. 1952, 22, 791.

14. Mann, F. D., and Hurn, M., Co-thromboplastin, a probable factor in coagulation of blood. Am. J. Physiol., 1951, 164, 105.

15. Alexander, B., Goldstein, R., and Landwehr, G., The prothrombin conversion accelerator of serum (SPCA): Its partial purification and its proper- ties compared with serum Ac-globulin. J. Clin. Invest., 1950, 29, 881.

16. Owren, P. A., Proconvertin, the new clotting factor. Scandinav. J. Clin. \& Lab. Invest., 1951, 3, 168.

17. Jacox, R. F., and Bays, R. F., The relationship of plasma prothrombin concentration and the degradation rate of serum "prothrombin-converting factor" during dicumarol therapy. Blood, 1950, 5, 313.

18. Field, J. B., Lanchantin, G., and Ware, A. G., Studies

- on thromboplastin inhibitors in serum. Federation Proc., 1953, in press.

19. Tocantins, L. M., Plasma antithromboplastic activity after severe hemorrhage. J. Clin. Invest., 1944., 23, 950.

20. Honorato, C. R., Hemofilia y sindromas hemofilicos: patogenia y tratamiento. Rev. méd. de Chile, 1952, 80, 1.

21. Steinberg, A., and Brown, W. R., A new concept regarding the mechanism of clotting and the control of hemorrhage. Am. J. Physiol., 1939, 126, P 638.

22. Blain, A. W., and Campbell, K. N., Hemostatic effect of oxalic acid. Clinical and experimental results, with a review of the literature. Arch. Surg., 1942, 44, 1117.

23. McGavack, T. H., Some recent advances in the treatment of hemophilia. Med. Clin. North America, 1940, 24, 791.

24. Page, R. C., Russell, H. K., and Rosenthal, R. L., Effect of oxalic acid intravenously on blood-coagulation time in three hemophiliacs. Ann. Int. Med., 1940, 14, 78.

25. Copley, A. L., and Lalich, J. T., The influence of blood transfusion and injections of bursa pastoris (Shepherd's Purse) extract on the clot resistance in two hemophiliacs. Am. J. M. Sc., 1942, 204, 665. 